\title{
Cultivation and Irrigation of Fernleaf Biscuitroot (Lomatium dissectum) for Seed Production
}

\author{
Myrtle P. Shock ${ }^{1}$ \\ Museu Amazônico, Universidade Federal de Amazonas, Rua Ramos Ferreira, \\ 1036, Centro, Manaus-AM, CEP: 69010-120, Brazil
}

Clinton C. Shock ${ }^{2,7}$ and Erik B.G. Feibert ${ }^{3}$

Oregon State University Malheur Experiment Station, 595 Onion Avenue, Ontario, OR 97914

Nancy L. Shaw ${ }^{4}$

USDA Forest Service, Rocky Mountain Research Station, 322 E. Front

Street, Suite 401, Boise, ID 83702

Lamont D. Saunders 5

Oregon State University Malheur Experiment Station, 595 Onion Avenue, Ontario, OR 97914

\author{
Ram K. Sampangi ${ }^{6}$ \\ University of Idaho, 29603 U of I Lane, Parma, ID 83660
}

Additional index words. rangeland restoration, medicinal plant, drip irrigation

\begin{abstract}
Native grass, forb, and shrub seed is needed to restore rangelands of the U.S. Intermountain West. Fernleaf biscuitroot [Lomatium dissectum (Nutt.) Mathias \& Constance] is a desirable component of rangelands. Commercial seed production is necessary to provide the quantity and quality of seed needed for rangeland restoration and reclamation efforts. Fernleaf biscuitroot has been used for hundreds if not thousands of years in the western United States as a source of food and medicine. Knowledge about fernleaf biscuitroot is confined to ethnobotanical reports, evaluation of some of its chemical constituents, and its role in rangelands. Products derived from fernleaf biscuitroot are sourced from wild plant populations. Little is known about fernleaf biscuitroot cultivation or its seed production. Variations in spring rainfall and soil moisture result in highly unpredictable water stress at flowering, seed set, and seed development of fernleaf biscuitroot. Water stress is known to compromise seed yield and quality for other seed crops. Irrigation trials were conducted at the Oregon State University Malheur Experiment Station at Ontario, OR, a location within the natural environmental range of fernleaf biscuitroot. It was anticipated that supplemental irrigation would be required to produce a seed crop in all years. Fernleaf biscuitroot was established through mechanical planting and cultivation on 26 Oct. 2005 in a randomized complete block design with four replicates; plot size was $9.1 \mathrm{~m} \times 3.04 \mathrm{~m}$ wide. Irrigation treatments were $0 \mathrm{~mm}, 100 \mathrm{~mm}$, and $200 \mathrm{~mm} / \mathrm{year}$ applied in four equal treatments 2 weeks apart, timed to begin with flowering and continue through seed formation. First flowering occurred in the third year after planting. Seed production increased from the fourth through the sixth year. Optimal irrigation for seed production was calculated as $140 \mathrm{~mm} / \mathrm{year}$.
\end{abstract}

Fernleaf biscuitroot or desert parsley [Lomatium dissectum (Nutt.) Mathias \& Constance] is a long-lived forb (non-woody perennial wildflower) with yellow, purple, or

\footnotetext{
Received for publication 5 July 2012. Accepted for publication 24 July 2012.

${ }^{1}$ Visiting Professor.

${ }^{2}$ Professor and Director.

${ }^{3}$ Senior Faculty Research Assistant.

${ }^{4}$ Research Botanist.

${ }^{5}$ Bioscience Research Technician.

${ }^{6}$ Formerly Extension Support Scientist.

${ }^{7}$ To whom reprint requests should be addressed; e-mail clinton.shock@oregonstate.edu.
}

leaves die back during midsummer. Plants are dormant during summer and do not resume growth with fall rains.

L. dissectum is self-fertile and protogynous and bee pollination is necessary for fernleaf biscuitroot seed production. Halictus sweat bees and Apis honeybees have been observed in production stands of fernleaf biscuitroot in Ontario, OR. In nature, there are other bees that specialize in pollinating fernleaf biscuitroot (Jim Cane, USDA-ARS Pollinating Insects-Biology, Management, and Systematics Research Unit, personal communication).

L. dissectum grows at elevations from sea level to $2500 \mathrm{~m}$ in western North America from southern California to British Columbia to the Rocky Mountains, mostly on rocky soils and in meadows (Meilleur et al., 1990; Soltis et al., 1997). Highly fertile, well-drained, and rocky soils are preferred environments where $L$. dissectum grows into large clumps 1.0 to $1.2 \mathrm{~m} \mathrm{(3} \mathrm{to} 4 \mathrm{ft}$ ) wide. It can grow in a range of precipitation regimes, including semiarid conditions. Three varieties, $L$. dissectum var. dissectum, $L$. dissectum var. eatonii, and $L$. dissectum var. multifidum, have been recognized indicating a considerable range of variation in the species; however, the varieties intergrade and there is disagreement as to whether varietal separation is warranted (Cronquist et al., 1997; Soltis et al., 1997).

\section{Current State of Knowledge}

Lomatium dissectum was used by Native American populations as food, medicine, and a piscicide. Specific uses described in historic, ethnobotanical records cannot be verifiably linked to $L$. dissectum as a result of the morphological similarities, especially in leaf morphology, among some Lomatium spp. and revisions of taxonomic classifications after the ethnobotanical studies (Ebeling, 1986; Jones, 1941; Meilleur et al., 1990). More than half of the Lomatium spp. are relatively rare with geographically restricted ranges (Soltis et al., 1997) making proper identification by a generally trained ethnobotanist less likely and perpetuating possible cases of folk underdifferentiation, the use of one folk name for two closely associated Linnaean species (Hunn and Brown, 2011). Of the 70 to 80 Lomatium species from western North America, only 20 occur in the ethnobotanical literature (Moerman, 2012).

Recent pharmacological research has demonstrated antiviral and antibacterial effects of $L$. dissectum. In laboratory studies, root extracts have inhibited rotavirus (a cause of severe childhood diarrhea), Mycobacterium tuberculosis (one cause of tuberculosis), and Mycobacterium avium (McCutcheon et al., 1995, 1997). Lomatium dissectum has shown no activity against a variety of other viruses and bacteria: bovine coronavirus (BCV, Coronaviridae), bovine herpesvirus type 1 (BHV1, Herpesviridae), bovine parainfluenza virus type 3 (BP13, Paramyxoviridae), bovine respiratory syncytial virus (BRSV, Paramyxoviriaize), vaccinia virus (Poxviridae), and 
vesicular stomatitis virus (VSV, Rhabdoviridae), Mycobacterium aurum, and Mycobacterium smegmatis (McCutcheon et al., 1995, 1997; Newton et al., 2002). L. dissectum also showed no antifungal activity in a screening against nine fungi (McCutcheon et al., 1994). McCutcheon and colleagues' studies (1994, 1995, and 1997) did not seek to isolate the specific active components in the roots. VanWagenen and Cardellina (1986) isolated two tetronic acids from $L$. dissectum as the principal antimicrobial metabolites based on the $\mathrm{CH}_{2} \mathrm{Cl}_{2}$-soluble extract from one whole plant. Four water-soluble constituents of $L$. dissectum that may inhibit bacterial and fungal growth have also been isolated, a flavonoid glycoside and three coumarin glycosides (VanWagenen et al., 1988). Links have yet to be drawn between the active components of the plant and the specific viruses or bacteria they act against.

Essential oils have been extracted and described from $L$. dissectum. The aromaticity was found to be primarily in the roots as opposed to the fruits and foliage. Based on the content of longifolene and ester in root oils, it may be possible to distinguish between $L$. dissectum var. dissectum, containing higher percentages of ester, and L. dissectum var. multifidum, containing more longifolene (Bairamian et al., 2004). The higher percentages of essential oils in $L$. dissectum roots is not a characteristic of the genus; the percentages are low in other studied Lomatium species, specifically $L$. dasycarpum, $L$. lucidum, L. macrocarpum, and L. utriculatum (Asuming et al., 2005). Neither studies of the essential oils nor pharmacological components of $L$. dissectum have discovered why its root extract can function as a piscicide (Bairamian et al., 2004; Meilleur et al., 1990). The geographic distribution of $L$. dissectum chemical properties is unknown.

On modern rangelands, $L$. dissectum serves as the host to Depressaria leptotaeniae moth larvae that feed on umbel sheaths and umbels (Clarke, 1953; Thompson, 1983). Depressaria betina larvae have also been found on the plants. Depressaria spp. have high degrees of host specificity. Lomatium dissectum is also a preferred food of grazing animals and some birds, its roots are eaten by rodents, and its seeds are a desirable food for some insects and mammals (Thompson, 1985, 1998). Natural plant populations of $L$. dissectum are also attacked by Puccinia spp. rust and insect pests including Phytomyza spp. leaf miner and Contarinia spp. gall flies (Thompson, 1998). We have observed aphids on native plant stands, but the species of aphids was not identified.

Germination of $L$. dissectum occurs after a vernalization period of three to four months with soil temperatures below $4.5^{\circ} \mathrm{C}$ (Scholten et al., 2009). The authors are unaware of any prior research into the production of $L$. dissectum leaves, roots, or other plant parts. Production of native forb seed crops depends on establishing best management practices for plant establishment, weed control, pest control, irrigation, and plant pollination. The focus of this article is on irrigation criteria for growing Lomatium dissectum for seed production. Irrigation directly affects seed yield. This research also included successful practices for plant establishment and weed control.

\section{Methods}

An irrigation trial for forb species including Lomatium dissectum, $L$. grayi, and $L$. triternatum was initiated in 2005 at the Malheur Experiment Station of Oregon State University, Ontario, OR. Lomatium dissectum seed came from wild collections made by the U.S. Forest Service near the Mann Creek Reservoir, Washington County, ID (lat. 44.401 ${ }^{\circ}$ $\mathrm{N}$, long. $-116.898^{\circ} \mathrm{W}, 850 \mathrm{~m}$ ) in 2002 and 2004.

The field, a Nyssa silt loam (coarse-silty, mixed, mesic, Xeric Haplodurid), was bedded into $76-\mathrm{cm}$ (30 in) rows. Drip tape (TTape TSX 515-16-340) was buried at $30 \mathrm{~cm}$ $(1 \mathrm{ft})$ depth and spaced $1.52 \mathrm{~m}(5 \mathrm{ft})$ apart beneath alternating interrow spaces. The flow rate for the drip tape was $4.16 \mathrm{~L} / \mathrm{min} / 100 \mathrm{~m}$ $(0.34 \mathrm{gal} / \mathrm{min} / 100 \mathrm{ft})$ at $55 \mathrm{kPa}(8 \mathrm{PSI})$ with emitters spaced $41 \mathrm{~cm}$ (16 in) apart, resulting in a water application rate of $1.7 \mathrm{~mm} / \mathrm{h}(0.066$ $\mathrm{in} / \mathrm{h})$. Water was filtered through sand media filters and application duration was controlled automatically.

Initially all Lomatium species were vernalized in the same manner. In 2005, seed was vernalized at $1{ }^{\circ} \mathrm{C}$ for 5.5 weeks until $L$. Seed was planted on 3 Mar. 2005 using a custom-made plot grain drill with disk openers at $1.25 \mathrm{~cm}$ depth with $65-100 \mathrm{seeds} / \mathrm{m}$ of row. Unlike the other two Lomatium species, $L$. dissectum did not emerge and the entire rows were replanted from the same seed lot at 65 seeds/m using the planter on 26 Oct. 2005 so that natural, winter vernalization could occur. In the spring of 2006, the plant stand was excellent.

In Apr. 2006, the L. dissectum strip was divided into four plots $9.1 \mathrm{~m}$ long. Each plot contained four $0.76-\mathrm{cm}$ rows. The grayi and $L$. triternatum began to germinate.

experimental design was randomized complete blocks with four replicates. The three irrigation treatments were control $(0 \mathrm{~mm} /$ year $)$, $100 \mathrm{~mm} /$ year (4 in/year), and $200 \mathrm{~mm} /$ year $(8$ in/year). The 100-mm and 200-mm irrigation treatments received four irrigations, $\approx 2$ weeks apart, starting during forb flowering. Each irrigation was scheduled to deliver $25 \mathrm{~mm}$ (100-mm treatment) or $50 \mathrm{~mm}(200-\mathrm{mm}$ treatment) through the drip system. The amount of water applied was measured by a water meter and recorded after each irrigation (Table 1). In 2007, irrigation treatments were inadvertently continued after the fourth irrigation doubling the planned irrigation amounts.

In Mar. 2007, the drip irrigation system was modified to allow separate irrigation of the forb species as a result of differing onset dates of flowering. The three Lomatium spp. were irrigated together. Flowering dates for Lomatium dissectum were recorded and are reported in conjunction with the irrigation dates in Table 2. Seed was harvested and cleaned by hand. Seed quality was not determined.

Soil volumetric water content was measured several times each season by a neutron probe. The neutron probe was calibrated by taking soil samples and probe readings at $20 \mathrm{~cm}, 50 \mathrm{~cm}$, and $80 \mathrm{~cm}$ depths during installation of the access tubes. The soil water content was determined volumetrically from the soil samples and regressed against the neutron probe readings separately for each soil depth.

The analysis of a soil sample taken on 22 Nov. 2005 showed a $\mathrm{pH}$ of $8.3,1.09 \%$ organic matter, 12 ppm $\mathrm{P}_{2} \mathrm{O}_{5}, 438$ ppm potassium, $27 \mathrm{ppm} \mathrm{SO}_{4}-\mathrm{S}, 4370 \mathrm{ppm}$ calcium, $456 \mathrm{ppm}$ magnesium, $81 \mathrm{ppm}$ sodium, $1.6 \mathrm{ppm}$ zinc, $0.6 \mathrm{ppm}$ copper, 4 ppm manganese, $3 \mathrm{ppm}$ iron, and $0.6 \mathrm{ppm}$ boron. Fertilization of the irrigation trial over the six years was minimal. On 27 Oct. 2006, $56 \mathrm{~kg} \cdot \mathrm{ha}^{-1}$ phosphorus $(\mathrm{P})$ and $2.2 \mathrm{~kg} \cdot \mathrm{ha}^{-1}$ zinc were injected through the drip tape. On 11 Nov. 2006, $112 \mathrm{~kg} \cdot \mathrm{ha}^{-1}$ nitrogen $(\mathrm{N})$ as urea was broadcast. On 9 Apr. 2009, $56 \mathrm{~kg} \cdot \mathrm{ha}^{-1} \mathrm{~N}$ and $11 \mathrm{~kg} \cdot \mathrm{ha}^{-1}$

Table 1. Water applied to the 100-mm and 200-mm irrigation treatments of Lomatium dissectum from 2006 to 2011 at Ontario, OR.

\begin{tabular}{lcccccr}
\hline & \multicolumn{5}{c}{ Actual water applied (mm) } \\
\cline { 2 - 7 } Target irrigation rates & 2006 & 2007 & 2008 & 2009 & 2010 & 2011 \\
\hline $100 \mathrm{~mm}$ & 124 & $233^{\mathrm{z}}$ & 137 & 104 & 103 & 102 \\
$200 \mathrm{~mm}$ & 221 & $448^{\mathrm{z}}$ & 218 & 204 & 202 & 202 \\
\hline
\end{tabular}

zrrigation in error.

Table 2. Lomatium dissectum flowering, irrigation, and seed harvest dates at Ontario, OR.

\begin{tabular}{|c|c|c|c|c|c|}
\hline \multirow[b]{2}{*}{$\mathrm{Yr}$} & \multicolumn{2}{|c|}{ Flowering } & \multicolumn{2}{|c|}{ Irrigation } & \multirow[b]{2}{*}{ Harves } \\
\hline & Start & End & Start & End & \\
\hline$\overline{2006}$ & \multicolumn{2}{|c|}{ No flowering } & 19 May & 30 June & None \\
\hline 2007 & \multicolumn{2}{|c|}{ No flowering } & 5 April & 24 June & None \\
\hline 2008 & \multicolumn{2}{|c|}{ Very little flowering } & 10 Apr. & 29 May & None \\
\hline 2009 & 10 Apr. & 7 May & 20 Apr. & 28 May & 16 June \\
\hline 2010 & 25 Apr. & 20 May & 15 Apr. & 28 May & 21 June \\
\hline 2011 & 8 Apr. & 10 May & 21 Apr. & 7 June & 20 June \\
\hline
\end{tabular}


$\mathrm{P}$ were applied through the drip irrigation system. On 3 May 2011, $56 \mathrm{~kg} \cdot \mathrm{ha}^{-1} \mathrm{~N}$ was applied through the drip irrigation system. Precipitation from October through June was $407,158,157,225,303$, and $374 \mathrm{~mm}$ for 2006 through 2011, respectively.

During the first two years (2005 and 2006), weeds were controlled primarily with cultivation and hand rouging. Herbicides were screened for their effectiveness and plant tolerance in other trials (Shock et al., 2010), but these products are not yet registered for use. In the irrigation trial, Prow $l^{\circledR}$ (pendimethalin) at $1.1 \mathrm{~kg}$ a.i./ha was broadcast on the soil surface for weed control on 17 Nov. 2006, 9 Nov. 2007, 15 Apr. 2008, 18 Mar. 2009, 4 Dec. 2009, and 17 Nov. 2010. Volunteer $^{\circledR}$ (clethodim) was broadcast at $0.57 \mathrm{~L} \cdot \mathrm{ha}^{-1}$ on $18 \mathrm{Mar}$. 2009. Hand rouging of weeds continued.

Seed yield was determined by manual once-over harvest of all mature seed stalks in the middle $7.5 \mathrm{~m}$ of the two center rows. Seed was cleaned from stalks and chaff and weighed. Seed yield means were compared by protected analysis of variance and nonlinear regression of seed yield against applied water.

\section{Results and Discussion}

Lomatium dissectum seed planted in the fall of 2005 germinated in the spring of 2006 after natural vernalization during the winter. The failure of $L$. dissectum to germinate in the spring of 2005 after 5.5 weeks vernalization is consistent with the findings of Scholten et al. (2009) who determined that 12 weeks of vernalization were necessary for emergence. Planting seed at $1.25 \mathrm{~cm}$ depth provided adequate emergence without supplemental irrigation. Subsequently, improved seedling establishment of native rangeland plants has been shown with fall seed planting under row cover (Shock et al., 2011). Lomatium dissectum vegetative growth was slow over the first three years (2006-08) and plants produced a few flowers in 2008. In 2009, vegetative growth and flowering for $L$. dissectum were greater and seed was harvested. L. dissectum, L. grayi, and L. triternatum were affected by Alternaria spp. fungi, but the infection was greatest and persistent on the L. dissectum. This infection likely delayed $L$. dissectum plant development and seed production. The resistance of $L$. dissectum to Alternaria spp. appears to vary by the selection chosen. The irrigation trial was planted using seed from a single $L$. dissectum seed collection site; other selections of $L$. dissectum used in different trials in Ontario, OR, have been observed to suffer from less Alternaria infection.

Lomatium dissectum produced seed in its fourth year of growth. Although changes in biomass were not tracked quantitatively, the plants have grown larger since their first seed set. The increase in plant size between 2009 and 2011 is consistent with the increased seed production across treatments (Table 3).
Plant irrigation needs for survival and some seed production are met by the natural precipitation in Ontario, OR, which lies within the native range of the species (Table 4); however, the addition of supplemental irrigation significantly influenced seed yield. In both 2010 and 2011, seed yield showed a quadratic response to irrigation rate (Fig. 1). In 2010 , seed yield was estimated to be maximized by $161 \mathrm{~mm}$ of applied water. In 2011, the optimum was at $127 \mathrm{~mm}$. Averaged over the three years, seed yield showed a quadratic response to irrigation rate and was estimated to be maximized by $140 \mathrm{~mm}$ of applied water [Fig. 1 and Eq. (4)]. The total of $140 \mathrm{~mm}$ may actually underestimate typical annual irrigation needs because both 2010 and 2011 were unusually wet before $L$. dissectum growth (Table 4).

Letting annual seed yield be $\mathrm{Y}$ in $\mathrm{kg} \cdot \mathrm{ha}^{-1}$ and applied irrigation to be $X$ in millimeters, the data in Figure 1 fits the following equations:

$$
\begin{gathered}
\mathrm{Y}_{2009}=80.3+1.55 * \mathrm{X} \\
\mathrm{R}^{2}=0.30, P(0.10) \\
\mathrm{Y}_{2010}=297+3.44 * \mathrm{X}-0.0107 * \mathrm{X}^{2}, \\
\mathrm{R}^{2}=0.51, P(0.05) \\
\mathrm{Y}_{2011}=635+14.3 * \mathrm{X}-0.0562 * \mathrm{X}^{2}, \\
\mathrm{R}^{2}=0.86, P(0.001) \\
\mathrm{Y}_{2009-2011}=330+6.91 * \mathrm{X}-0.0247 * \mathrm{X}^{2} \\
\mathrm{R}^{2}=0.72, P(0.01)
\end{gathered}
$$

Because substantial seed yields of $L$. dissectum were achieved under cultivation, it is reasonable to assume that other plant parts

\begin{tabular}{|c|c|c|c|c|}
\hline & $0 \mathrm{~mm}$ & $100 \mathrm{~mm}$ & $200 \mathrm{~mm}$ & LSD $(0.05)$ \\
\hline Yr & \multicolumn{4}{|c|}{-------------------------------------------(kg/ha)----------------------------------------- } \\
\hline 2006 & \multicolumn{4}{|c|}{ No flowering } \\
\hline 2007 & \multirow{2}{*}{\multicolumn{4}{|c|}{$\begin{array}{c}\text { No flowering } \\
\text { Verv little flowering }\end{array}$}} \\
\hline 2008 & \multicolumn{3}{|c|}{ Very little flowering } & \\
\hline 2009 & 56.7 & 282.8 & 367.1 & NS \\
\hline 2010 & 297.8 & 535.2 & 559.6 & NS \\
\hline 2011 & 635.6 & 1503.9 & 1247.5 & 202.6 \\
\hline 3-year average & 330 & 774 & 724.7 & 219.2 \\
\hline
\end{tabular}
could also be grown for medicinal or pharmacological use.

Seed yield in 2011 was substantially higher at all irrigation levels. The relatively high yield without any irrigation in 2011 may have been the result of greater plant

Table 3. Lomatium dissectum seed production by year and irrigation treatment at Ontario, OR.

LSD = least significant difference; $\mathrm{NS}=$ non-significant.

Table 4. Natural precipitation in Ontario, OR, over the course of the irrigation trial before and during Lomatium dissectum growth and seed production.

\begin{tabular}{lcccc}
\hline & \multicolumn{2}{c}{} & $\begin{array}{c}\text { Growing degree-days } \\
\left(10 \text { to } 30^{\circ} \mathrm{C}\right)\end{array}$ \\
\cline { 2 - 5 } Yr & October to June & January to June & April to June & January to June \\
\hline 2006 & 407 & 229 & 79 & 622 \\
2007 & 158 & 79 & 48 & 671 \\
2008 & 157 & 74 & 30 & 520 \\
2009 & 225 & 147 & 99 & 571 \\
2010 & 303 & 211 & 109 & 433 \\
2011 & 374 & 211 & 98 & 373 \\
21 -year average & 248 & 147 & 69 & 569 \\
\hline
\end{tabular}

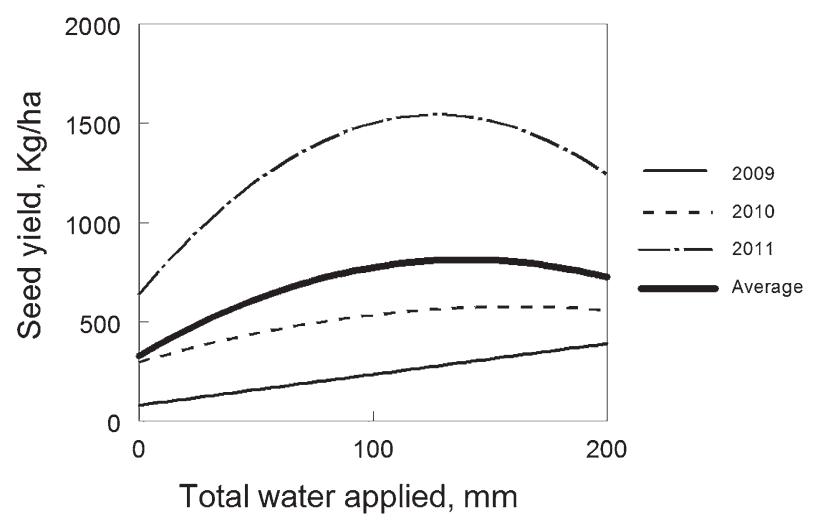

Fig. 1. Lomatium dissectum seed yield at Ontario, OR responded linearly to irrigation in 2009 and in a quadratic fashion in 2010 and 2011. The seed yield response averaged over the three years was also quadratic. 
Table 5. Soil moisture averaged over 0.20-, 0.50-, and 0.80-m depths as determined by neutron probe in plots where Lomatium dissectum was grown with variable irrigation, 2009-2011, Ontario, OR.

\begin{tabular}{|c|c|c|c|c|c|}
\hline \multirow[b]{3}{*}{ Yr } & \multirow[b]{3}{*}{ Calendar day } & \multirow[b]{3}{*}{ Day of the yr } & \multicolumn{3}{|c|}{ Annual irrigation (mm) } \\
\hline & & & 0 & 100 & 200 \\
\hline & & & \multicolumn{3}{|c|}{ Percent volumetric water content } \\
\hline \multicolumn{6}{|l|}{2009} \\
\hline & 24 Apr & 114 & 19.62 & 22.45 & 29.26 \\
\hline & 7 May & 127 & 21.89 & 22.63 & 28.46 \\
\hline & 20 May & 140 & 19.19 & 22.84 & 30.93 \\
\hline & 1 June & 152 & 18.42 & 20.76 & 29.56 \\
\hline \multicolumn{6}{|l|}{2010} \\
\hline & 13 Apr. & 103 & 20.20 & 21.40 & 26.09 \\
\hline & 4 May & 124 & 19.00 & 23.98 & 27.00 \\
\hline & 12 May & 132 & 18.20 & 21.15 & 27.65 \\
\hline & 26 May & 146 & 18.67 & 19.67 & 27.21 \\
\hline & 18 June & 169 & 18.55 & 21.74 & 29.17 \\
\hline \multicolumn{6}{|l|}{2011} \\
\hline & 31 Mar. & 90 & 25.59 & 27.57 & 30.26 \\
\hline & 22 Apr. & 112 & 21.49 & 24.86 & 30.27 \\
\hline & 17 May & 137 & 19.10 & 22.99 & 27.13 \\
\hline & 3 June & 154 & 18.69 & 22.12 & 28.56 \\
\hline
\end{tabular}

development and substantially wetter soil at the beginning of the 2011 growing season (Table 5).

\section{Conclusions}

Lomatium dissectum was successfully established with mechanical fall planting after a spring planting failed. Drip irrigation was an effective irrigation system. Seed production was delayed until the fourth year and continued to increase through the sixth crop year. Considering seed yield over the fourth through sixth years, the optimal irrigation amount at Ontario, OR, was calculated to be $140 \mathrm{~mm} /$ year.

\section{Literature Cited}

Asuming, W.A., P.S. Beauchamp, J.T. Descalzo, B.C. Dev, V. Dev, S. Frost, and C.W. Ma. 2005. Essential oil composition of four Lomatium Raf. species and their chemotaxonomy. Biochem. Syst. Ecol. 33:17-26.

Bairamian, S., P.S. Beauchamp, J.T. Descalzo, B.C. Dev, V. Dev, S.C. Frost, and C.V. Nguyen. 2004. California Lomatiums part III. Composition of the hydrodistilled oils from two varieties of Lomatium dissectum. Isolation of a new hydrocarbon. Journal of Essential Oil Research 16:461-468.

Clarke, J.F.G. 1953. Host relationships of moths of the genera Depressaria and Agonopterix, with
Meilleur, B.A., E.S. Hunn, and R.L. Cox. 1990 Lomatium dissectum (Apiaceae): Multi-purpose plant of the Pacific Northwest. Journal of Ethnobiology 10:1-20.

Moerman, D. 2012. Native American ethnobotany: A database of foods, drugs, dyes and fibers of Native American peoples, derived from plants. 2 Feb. 2012. <http://herb.umd.umich.edu/>.

Newton, S.M., C. Lau, S.S. Gurcha, G.S. Besra, and C.W. Wright. 2002. The evaluation of forty-three plant species for antimycobacterial activities; isolation of active constituents from Psoralea corylifolia and Sanguinaria canadensis. J. Ethnopharmacol. 79:57-67.

Scholten, M., J. Donahue, N.L. Shaw, and M.D. Serpe. 2009. Environmental regulation of dormancy loss in seed of Lomatium dissectum (Apiaceae). Ann. Bot. (Lond.) 103:1091-1101.

Shock, C.C., E.B.G. Feibert, C.A. Parris, L.D. Saunders, and N.L. Shaw. 2011. Operational success of direct surface seeding strategies for establishment of Intermountain West native plants, p. 179-185. In: Shock, C.C. (ed.). Oregon State University Agricultural Experiment Station, Malheur Experiment Station Annual Report 2010, Department of Crop and Soil Science Ext/CrS 132.

cerciptions of new species. Smithsonian MisInstitution, Washington, DC.

Cronquist, A.J., N.H. Holmgren, and P.K. Holmgren. 1997. Intermountain flora: Vascular plants of the intermountain west, U.S.A. Volume three, part A, subclass Rosidae (except Fabales). New York Botanical Garden, New York, NY.

Ebeling, W. 1986. Handbook of Indian foods and fibers of arid America. University of California, Berkeley, CA.

Hunn, E.S. and C.H. Brown. 2011. Linguistic ethnobiology, p. 319-333. In: Anderson, E.N., D.M. Pearsall, E.S. Hunn, and H.J. Turner (eds.). Ethnobiology. Wiley-Blackwell, Hoboken, NJ.

Jones, V.H. 1941. The nature and status of ethnobotany. Chron. Bot. VI:219-221.

McCutcheon, A.R., S.M. Ellis, R.E.W. Hancock, and G.H.N. Towers. 1994. Antifungal screening of medicinal plants of British Columbian native peoples. J. Ethnopharmacol. 44:157169.

McCutcheon, A.R., T.E. Roberts, E. Gibbons, S.M. Ellis, L.A. Babiuk, R.E.W. Hancock, and G.H.N. Towers. 1995. Antiviral screening of British Columbian medicinal plants. J. Ethnopharmacol. 49:101-110.

McCutcheon, A.R., R.W. Stokes, L.M. Thorson, S.M. Ellis, R.E.W. Hancock, and G.H.N. Towers. 1997. Anti-mycobacterial screening of British Columbian medicinal plants. International Journal of Pharmacognosy 35: $77-83$.
Shock, C.C., J. Ishida, E.B.G. Feibert, and N. Shaw. 2010. Native perennial forb tolerance to repeated annual applications of postemergence herbicides. Oregon State University Agricultural Experiment Station 2009 Annual Report. p. 213-217.

Soltis, P.S., D.E. Soltis, and T.L. Norvell. 1997. Genetic diversity in rare and widespread species of Lomatium (Apiaceae). Madrono 44:5973.

Thompson, J.N. 1983. The use of ephemeral plant parts on small host plants: How Depressaria leptotaeniae (Lepidoptera: Oecophoridae) feeds on Lomatium dissectum (Umbelliferae). J. Anim. Ecol. 52:281-291.

Thompson, J.N. 1985. Postdispersal seed predation in Lomatium spp. (Umbelliferae): Variation among individuals and species. Ecology 66 1608-1616.

Thompson, J.N. 1998. Coping with multiple enemies: 10 years of attacks on Lomatium dissectum plants. Ecology 79:2550-2554.

VanWagenen, B.C. and J.H. Cardellina, II. 1986 Native American food and medicinal plants 7. antimicrobial tetronic acids from Lomatium dissectum. Terrahedron 42:1117-1122.

VanWagenen, B.C., J. Huddleston, and J.H and medicinal plants, 8 . water-soluble constituents of Lomatium dissectum. J. Nat. Prod. 51: 136-141. Cardellina, II. 1988. Native American food 